Article

\title{
Moringin, A Stable Isothiocyanate from Moringa oleifera, Activates the Somatosensory and Pain Receptor TRPA1 Channel In Vitro
}

\author{
Gigliola Borgonovo ${ }^{1}$, Luciano De Petrocellis ${ }^{2}{ }^{\circledR}$, Aniello Schiano Moriello ${ }^{2,3}$, Simona Bertoli ${ }^{1}{ }^{1}$, \\ Alessandro Leone ${ }^{1}\left(\mathbb{D}\right.$, Alberto Battezzati ${ }^{1}$, Stefania Mazzini ${ }^{1}$ (D) and Angela Bassoli ${ }^{1, *(D)}$ \\ 1 Department of Food, Environment and Nutrition-DeFENS, University of Milan, Via Celoria 2, \\ I-20133 Milano, Italy; gigliola.borgonovo@unimi.it (G.B.); simona.bertoli@unimi.it (S.B.); \\ alessandro.leone1@unimi.it (A.L.); alberto.battezzati@unimi.it (A.B.); stefania.mazzini@unimi.it (S.M.) \\ 2 Endocannabinoid Research Group-Institute of Biomolecular Chemistry-CNR, Pozzuoli, I-87078 Napoli, Italy; \\ luciano.depetrocellis@icb.cnr.it (L.D.P.); aniello.schianomoriello@icb.cnr.it (A.S.M.) \\ 3 Epitech Group SpA, Saccolongo, 35030 Padova, Italy \\ * Correspondence: angela.bassoli@unimi.it; Tel.: +39-0250316815
}

Academic Editor: Hosam O. Elansary

Received: 29 January 2020; Accepted: 20 February 2020; Published: 22 February 2020

check for updates

\begin{abstract}
Moringa oleifera Lam. is a tropical plant widely used in traditional medicines and as a food supplement. It is characterized by the presence of glucosinolates and isothiocyanates; the stable isothiocyanate 4-[( $\alpha$-L-rhamnosyloxy)benzyl]isothiocyanate (moringin) has been widely studied for its bioactivity as hypoglycemic, antimicrobial, anticancer and in particular for its involvement in nociception and neurogenic pain. Moringa extracts and pure moringin were submitted to in vitro assays with the somatosensory TRPA1 ion channel, proving that moringin is a potent and effective agonist of this receptor involved in nociceptive function and pain states. Moringin do not activate or activates very weakly the vanilloids somatosensory channels TRPV1,2,3 and 4, and the melastatin cooling receptor TRPM8. The comparison of moringin's activity with other known agonists of natural origin is also discussed.
\end{abstract}

Keywords: Moringa oleifera; moringin; TRPA1 ion channel; isothiocyanates

\section{Introduction}

\subsection{Moringa oleifera Lam., A Multi-Purpose Tree}

Moringa oleifera Lam., (family Moringaceae, order of Capparales), is a tropical and subtropical plant diffused worldwide. It has been used in traditional medicines since long time.

The plant is known with the common names of moringa, drumstick tree (from the long, slender, triangular seed-pods) or horseradish tree (from the pungent taste of the roots, resembling horseradish).

Some recent pharmacological studies appear to validate the claimed medicinal uses of the plant, primarily the leaves, which include antioxidant, anti-carcinogenic, anti-diabetic, anti-inflammatory and anti-hypertensive properties, as well as the ability to protect against hepatic damage. The phytochemistry and pharmacology of moringa has been recently reviewed [1,2].

Due to its nutrient constitution, M. oleifera is used in several regions to treat malnutrition. Its bitter and pungent taste sometimes limits the consumers' acceptance level, especially in Western cultures not familiar with it. Recently some of us have studied the taste acceptability of moringa leaf power in meals, and it proved to be low, while an important hypoglycemic effect was well demonstrated by trials and evaluating the long-term effects on glycaemia. [3]. 
The characterization of $M$. oleifera leaf extract have recorded a total of 59 bioactive compounds, including amino and organic acids, nucleosides, glucosinolates, lignans, phenolic acids, and flavonoids [4].

Glucosinolates (GLSs) are secondary metabolites especially abundant in plants of the order of Capparales. Crucifer vegetables in addition to GLSs contain myrosinase, a specific thioglucosidase, located in separate cell compartments. When the enzyme and the substrates come in contact in an aqueous environment, for example due to tissue damage or chewing, myrosinase causes immediate hydrolysis of GLSs which produces sugars and an unstable aglycon fragments [5] that after structural rearrangements forms various compounds including isothiocyanates (ITCs). Both GLSs and ITCs are largely investigated for their medicinal effects.

Glucomoringin is the main GLS in moringa [6] and moringin is the corresponding ITC (Figure 1).
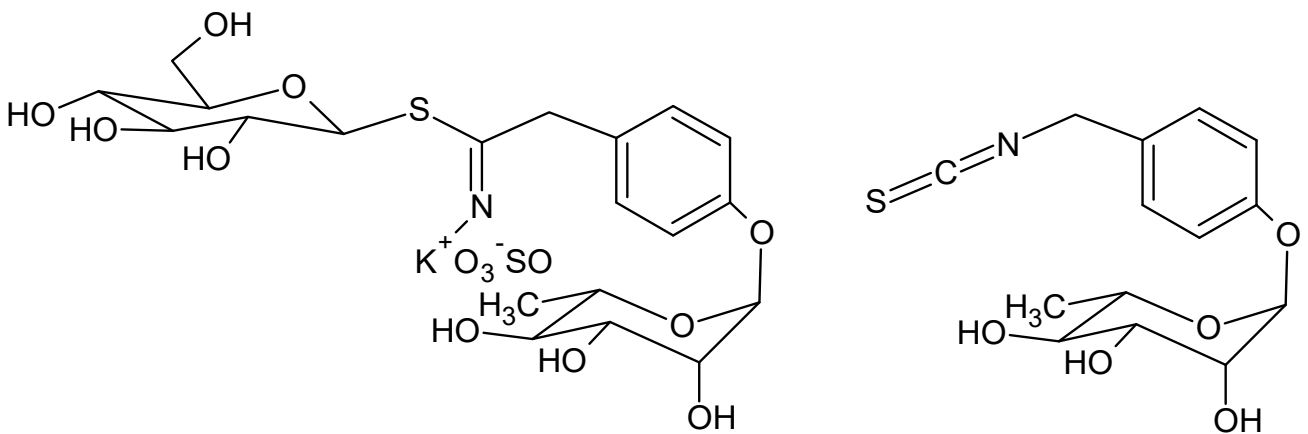

Figure 1. Structure of glucomoringin (left) and moringin (right).

Due to the presence of the polar O-glycosylated phenol substituent, moringin is a solid, odorless and relatively stable compound at room temperature; these are uncommon features for most isothiocyanates obtained by crucifer plants, such as benzyl- and allylisothiocyanate from mustard which are usually small and volatile compounds, with a pungent smell. [7].

The biological activity of moringin extracts and moringin itself attracted the attention of a number of researchers in different areas. This phyto-compound possesses in fact a wide range of biological activities, including antioxidant [8], antimicrobial [9], antibacterial [6], antifungal and antiviral [10-12], and deterrent effects towards some insects. [13].

Moringin is also studied for medicine applications: beside the hypoglycaemic effects described above, it shows anti-inflammatory [14] and antitumor effect [15,16]. Moringin has shown potential in the stem cell-based therapeutic treatments in neurodegenerative diseases such as Parkinsons' and Altzheimer's diseases and it protects against neurodegenerative disorders [17,18].

A comparison between moringin and cannabidiol in the treatment of stem cells as a therapeutic approach for inflammation in neurodegenerative diseases has been also recently discussed [19]. Moringin has been shown to defends cerebral tissue and prevent severe damage induced by focal ischemia/reperfusion [20]; another study on the Amyotrophic Lateral Sclerosis (ALS) transgenic model revealed a significative interference of moringin with the pathophysiology mechanisms that induced the development of the disease. The moringin administration was able to delay the disease onset of about two weeks [21].

Recently the role of $\mathrm{H}_{2} \mathrm{~S}$ release from glucosinolates/isothiocyanates as a potent mechanism of protective action in the cardiovascular compartment and in the nervous system has been reported [22], as well as the role of $\mathrm{H}_{2} \mathrm{~S}$-mediated pain-relieving effects of natural and synthetic isothiocyanates [23].

The involvement of moringin in nociception has been often reported. Potential analgesic activities, in vivo anti-arthritic and evidences of broad spectrum of anti-nociceptor effects were described in the literature. [24,25].

Recently Giacoppo and coworkers [26] reported the efficacy of 2\% moringin cream treatment in reducing clinical and histological disease score, as well as in alleviating neuropathic pain. A formulation 
with moringin encapsulated in $\alpha$-cyclodextrin showed anti-inflammatory effects in LPS activated macrophages, suggesting a therapeutic approach for inflammatory diseases. [27].

\subsection{TRPA1 Channel in Nociception}

Previously called ANKTM1 (ankyrin repeat-containing ion channel 1), Transient Receptor Potential type Ankyrin (TRPA1) channel is the only member of the TRPA sub-family reported in mammals [28]. TRPA1 is a member of the large TRP family of ion channels, is a $\mathrm{Ca}^{2+}$ permeable non-selective cation channel functioning in many different cell processes as polymodal sensor involved in the perception of several stimuli among which cold, pungent compounds, airborne irritants and cannabinoids as well as in neurogenic inflammatory responses and pain perception $[29,30]$. TRPA1 is expressed in neuronal dorsal root and trigeminal ganglion neurons [31] and non-neuronal tissues and cells such as skin keratinocytes [32,33] and airway epithelial cells [34]; its activation on trigeminal nerves may produce head pain [35].

TRPA1 is activated by a large number of electrophilic, pungent compounds such as isothiocyanates and unsaturated aldehydes [36], pungent compounds present in garlic [37,38], ketones and thiosulfinates common in many plants, particularly in Brassicaceae and are often characterized a by a bitter and pungent taste, and the plant-derived cannabinoid receptor agonists THC [39]. These compounds have very different structures, most of them may covalently modify intracellular cysteines and/or lysines opening the channel [40,41]. However, it has been reported the presence of alternative activation mechanisms so that TRPA1 may be activated by other plant compounds that not interact with cysteines [42]. Many of them, included Moringa oleifera, are important crops for human and animal diets and are also commonly used as traditional remedies. Allylisothiocyanate (mustard oil) is the reference agonist for TRPA1; other isothiocyanates as benzyl-, phenylethyl-, isopropyl-, and methyl-isothiocyanates have been proved to activate TRPA1 in vitro [43,44]. The role of TRPA1 channel in pain has been extensively reviewed $[45,46]$.

\subsection{Aim of This Work}

The aim of this work is to assess the activity of moringin on TRPA1 ion channel. At this aim, we prepared extracts from leaves of Moring oleifera using solvents of different polarities. Moreover we isolated moringin (4-[( $\alpha$-L-rhamnosyloxy)benzyl]isothiocyanate) from moringa leaves; extracts and isolated moringin were submitted to in vitro assays with cloned TRPA1 receptor. Moringin turned out to be a potent agonist of TRPA1. Other ion channels, as the vanilloids TRPV1-4 and TRPM8 were also tested giving very low (for TRPV1) or no measurable response.

\section{Results}

\subsection{Preparation of Extracts and Isolation of Moringin}

Leaves of Moringa oleifera were used as dry powdered leaves or frozen leaves. Starting from moringa powder we obtained four extracts using solvents with increasing polarity: hexane (E1), diethylether (E2), dichloromethane (E3), and ethanol (E4). For extracts E5 and E6, the extraction of moringa leaves was performed in order to optimize in situ the hydrolysis of glucomoringin in moringin by myrosinase. At this aim, frozen leaves were finely crushed at room temperature to free the enzyme before extraction with water and methanol respectively.

Similarly, moringin (purity $>94 \%$, HPLC) was obtained from the methanolic extract of frozen moringa leaves following a literature method [47]. The structure was confirmed by NMR analysis in comparison with literature data $[13,48]$.

\subsection{In Vitro Assays}

Extracts (E1-6) and pure moringin were submitted to in vitro assays with the TRPA1 receptor. 
Allylisothiocyanate (AITC) is conventionally used as the reference agonist for TRPA1 and was used to establish the relative efficacy for each tested compound. Antagonist/desensitizing behavior was also measured. The results are shown in Table 1.

Table 1. In vitro assays on transient receptor potential ankyrin 1 (TRPA1) ion channel.

\begin{tabular}{|c|c|c|c|}
\hline \multirow[b]{2}{*}{ Sample } & \multicolumn{3}{|c|}{ TRPA1 } \\
\hline & Efficacy (\% AITC $100 \mu \mathrm{M})$ & Potency $\mathrm{EC}_{50} \mu \mathrm{g} / \mathrm{mL}$ & $\begin{array}{l}\text { Inhibition } \text { IC }_{50} \mu \mathrm{g} / \mathrm{mL} \\
\quad(A I T C 100 \mu \mathrm{M})\end{array}$ \\
\hline E1 (hexane) & $112.6 \pm 4.9$ & $9.0 \pm 0.9$ & $25.7 \pm 1.4$ \\
\hline E2 (ethylether) & $104.1 \pm 7.7$ & $15.0 \pm 2.9$ & $40.9 \pm 1.4$ \\
\hline E3 (dichloromethane) & $64.8 \pm 1.7$ & $>20$ & $>50$ \\
\hline E4 (ethanol) & $19.6 \pm 1.9$ & $>20$ & $>50$ \\
\hline E5 (water) ${ }^{1}$ & $37.5 \pm 1.5$ & $>20$ & $>50$ \\
\hline E6 (methanol) ${ }^{1}$ & $99.0 \pm 1.7$ & $1.3 \pm 0.1$ & $1.2 \pm 0.2$ \\
\hline Moringin & $102.6 \pm 1.1$ & $3.14 \pm 0.16 \mu \mathrm{M}$ & $3.60 \pm 0.05 \mu \mathrm{M}$ \\
\hline
\end{tabular}

${ }^{1}$ Samples E1-4 from dry leaves; E5 and E6 from frozen leaves. AITC = allylisothiocyanate.

Among the extracts from dry powder, only E1 and E2 show some activity whereas E3, E4 and E5 are inactive. The most active extract is E6, obtained from frozen leaves, with an efficacy of $99 \%$ and a potency of $1.3 \mu \mathrm{g} / \mathrm{mL}$.

Pure moringin has an efficacy of $102.6 \pm 1.1 \%$ and a potency of $3.14 \pm 0.16 \mu \mathrm{M}$ that is comparable to that of AITC $\left(\mathrm{EC}_{50}=1.43 \pm 0.04 \mu \mathrm{M}\right)$, in good agreement with what we previously reported [49]. Moringin has emerged as one of the most potent natural agonists of TRPA1 in vitro, with a potency very close to that of curcumin $\left(\mathrm{EC}_{50}=3.3 \mu \mathrm{M}\right)$ [50]. The selective TRPA1 channel antagonist AP18 (4-(4-chlorophenyl)-3-methyl-3-buten-2-one oxime) inhibited moringin and AITC-induced effects in TRPA1-HEK293 cells. We found that AP18 (at $50 \mu \mathrm{M}$ ), reduced elevation of intracellular $\mathrm{Ca}^{2+}$ in human embryonic kidney (HEK)-293 cells stably transfected with rat TRPA1 (rTRPA1-HEK-293) by 68.6 $\pm 3.0 \%$ and $64.1 \pm 2.7 \%$ respectively by AITC $(100 \mu \mathrm{M})$ and moringin $(10 \mu \mathrm{M})$. The dose-response curve for moringin is shown in Figure 2.

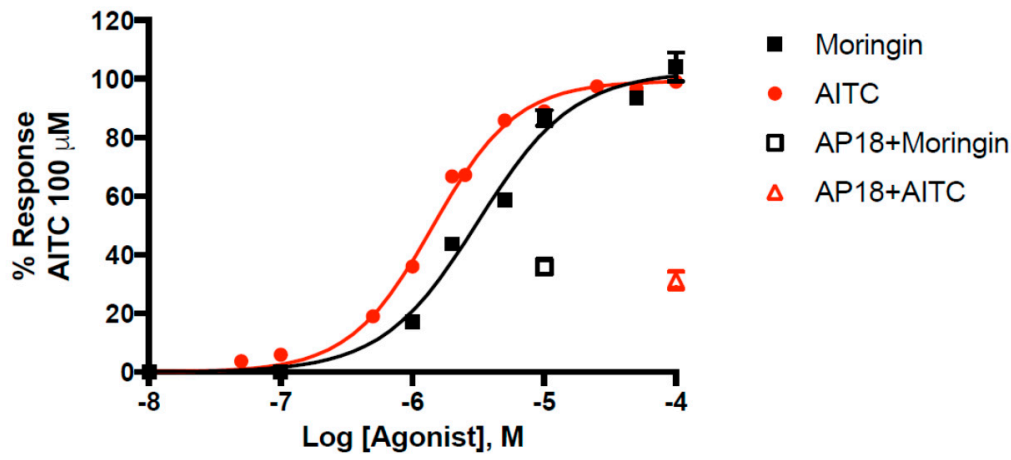

Figure 2. Dose-related effect of moringin and allylisothiocyanate (AITC) on elevation of intracellular $\mathrm{Ca}^{2+}$ in human embryonic kidney (HEK)-293 cells stably transfected with rat TRPA1 (rTRPA1-HEK-293). AP18 = 4-(4-chlorophenyl)-3-methyl-3-buten-2-one oxime. Data are expressed as percentages of the effect observed with AITC $100 \mu \mathrm{M}$.

Figure 3 shows the dose-response curves to evaluate the desensitizing behavior of moringin, a well-known effect for TRPA1 agonists [51,52].

Moringin 2 desensitizes TRPA1 with an $\mathrm{IC}_{50}=3.60 \pm 0.05 \mu \mathrm{M}$ while AITC activates and subsequently desensitize TRPA 1 with an $\mathrm{IC}_{50}=1.71 \pm 0.05 \mu \mathrm{M}$. Moringin has a very strong desensitizing effect which is typical of TRP channels, the effect of AITC $100 \mu \mathrm{M}$ administered after a pre-incubation of TRPA1-HEK293 cells with moringin $50 \mu \mathrm{M}$, is completely inhibited. 


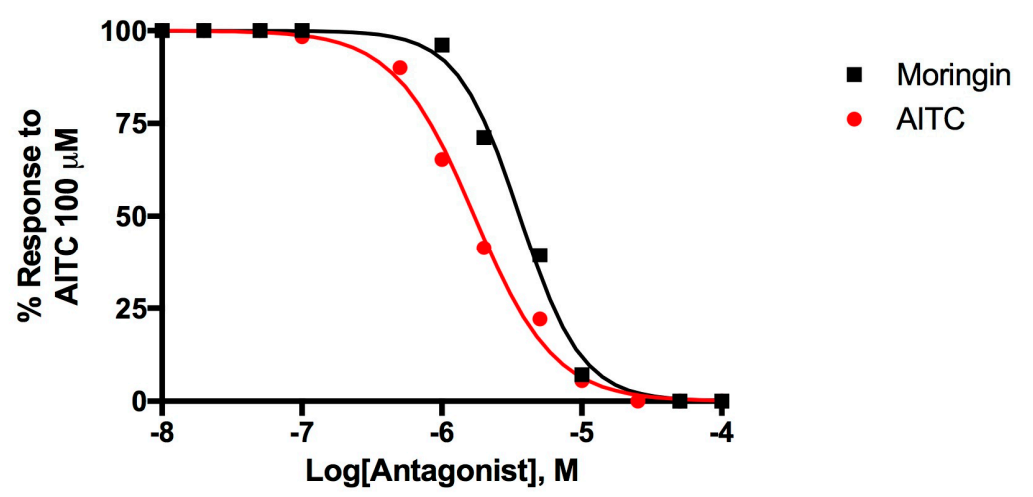

Figure 3. Dose-related effect of 5-min pre-incubation of rTRPA1-HEK-293 cells with moringin and allylisothiocyanate (AITC) on the AITC $(100 \mu \mathrm{M})$-induced elevation of intracellular $\mathrm{Ca}^{2+}$. Data are expressed as percentages of the effect observed with AITC $(100 \mu \mathrm{M})$ alone.

Moringin is likely the active principle responsible of the activity of the alcoholic extract E6. Moringin is in fact detectable in this extract by TLC analysis and comparison with purified sample. The activity is much lower in $\mathrm{E} 4$, prepared from dried powder, where myrosinase has been inactivated and the hydrolysis of glucosinolate to give moringin is therefore very slow.

Moringin was then assayed with other receptors of the vanilloid family, i.e., TRPV1,2,3,4, and with the melastatin cooling receptor TRPM8. For TRPV1 the potency resulted weak and for the others the efficacy is lower than $10 \%$. Results are shown in Table 2.

Table 2. In vitro assays of moringin on TRPV and TRPM8 ion channels.

\begin{tabular}{ccccc}
\hline & Efficacy $(\%$ Ionomycin $\mathbf{4} \boldsymbol{\mu M})$ & Potency $^{\mathbf{1}} \mathbf{E C}_{\mathbf{5 0}} \boldsymbol{\mu M}$ & IC $_{\mathbf{5 0}} \boldsymbol{\mu} \mathbf{M}$ & Reference Agonist \\
\hline TRPV1 & $46.8 \pm 0.7$ & $20.4 \pm 1.3$ & $>50$ & capsaicin $0.1 \mu \mathrm{M}$ \\
TRPV2 & $<10$ & n.a. & $>100$ & LPC $3 \mu \mathrm{M}$ \\
TRPV3 & $<10$ & n.a. & $>100$ & thymol $100 \mu \mathrm{M}$ \\
TRPV4 & $<10$ & n.a. & $>100$ & GSK1016790A $10 \mathrm{nM}$ \\
TRPM8 & $<10$ & n.a. & $>100$ & icilin $0.25 \mu \mathrm{M}$ \\
\hline
\end{tabular}

${ }^{1}$ When the efficacy is lower than $10 \%$ the compound is considered not active (n.a.) and potency cannot be calculated.

\section{Discussion}

The use of moringa and its extracts for medicinal purposes is well established; in particular, recent evidences for its analgesic activity has been reported. Pharmacological evaluation of non-polar and/or polar extracts was explored through several experimental nociception models as formalin test, carrageenan-induced paw edema and arthritis with subcutaneous injection of collagen in rats [24]. The authors found that both polar and non-polar extracts produced significant inhibition of nociceptive behavior.

Phytochemical analysis allowed to identify several molecules able to exert an analgesic effect, as kaempferol-3-glucoside, in the polar extract and fatty acids like chlorogenic and palmitic acid, among others, in the non-polar extract. In moringa polar extracts the antinociceptive activity was suggested to be modulated via opioid receptors at the central, but not peripheral, antinociceptive level [53].

Moringa leaves have also been reported to contain various types of flavonol glycosides, as well as kaempferol, rutin, and quercetin [54]. Additionally, these flavonols are TRPA1 agonists [55].

In this paper we report that moringin, the main stable isothiocyanate in moringa, is itself a very effective and potent agonist of TRPA1. This data reinforces the hypothesis that this ion channel could be one of the mediators of the analgesic effect of the plant. The activity of moringin is selective, since no other receptors of the TRPV vanilloid family nor the TRPM8 are activated. 
Many other plants are rich in TRPA1 agonists, and their importance as functional ingredients against inflammation and pain is rapidly growing, particularly when the plant is a food plant and therefore a cheap and accessible source of such medicinal principles. We compared the $\mathrm{EC}_{50}$ values of several natural agonists reported for rTRPA1 (Figure 4).

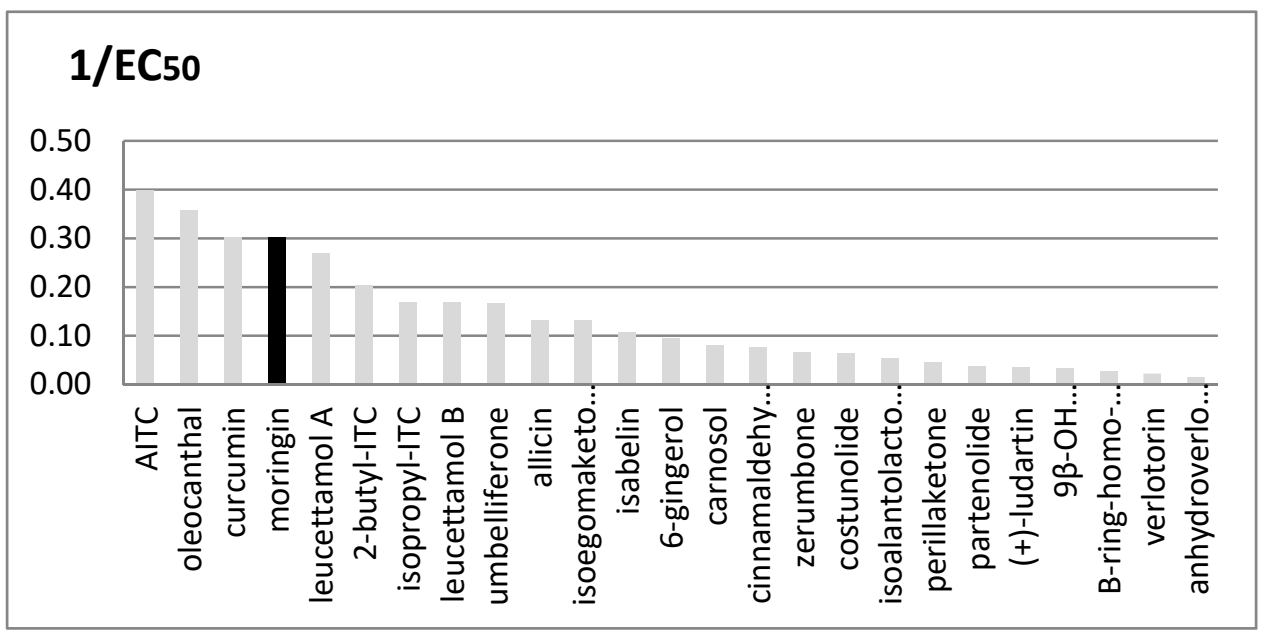

Figure 4. Comparison between in vitro rTRPA1's activity of many natural known agonists. Potency is expressed as $1 / \mathrm{EC}_{50} ; \mathrm{EC}_{50}$ values are given in $\mu \mathrm{M}$ units. Moringin from Moringa oleifera is shown in black.

It is interesting to note that the three most active compounds in this group, i.e., oleocanthal, curcumin and moringin, come from widely distributed food plants.

Moringa oleifera is a very promising source of functional bioactives for its large diffusion in tropical and sub-tropical areas and its ability to grow in arid climatic conditions where nutrition and health issues are both critical for populations.

Our data on extracts E1 and E2, obtained by hexane and diethylether, show that beside moringin, other non-polar or low-polar compounds can contribute to the activity on TRPA1; this data is in agreement with the previously reported identification of analgesic effects also in non-polar extracts [24].

The concentration of moringin in Moringa oleifera preparations is dependent by the presence of endogenous myrosinase and it has been shown to diminish in formulations as powder dry leaves, where the enzyme has been inactivated by thermal treatment. For food supplements, the use of fresh leaves, or extracts from fresh or frozen leaves allows to maximize the concentration of the TRPA1 active compound moringin. As an alternative, the in situ formation of moringin from glucomoringin could be promoted by chemical hydrolysis and this could be a suggestion for further research directions and applications.

\section{Materials and Methods}

\subsection{Plant Material}

Moringa leaves were collected in 2018 from trees experimentally cultivated at Centro Experimental de Formación Agrícola (CEFA), Ministerio de Desarrollo Económico, República Árabe Saharaui Democrática, an oasis created in 2009 next to Rabouni camp (Tindouf, South-Western Algeria). The leaves were dried through a shade-dried process at room temperature, and ground to a fine powder with an electric grinder. One portion was used for preparation of extracts E1-4. Another portion of fresh leaves was collected and immediately frozen after transportation. This sample of frozen leaves has been used for the preparation of extracts E5 and E6. 


\subsection{Chemicals and Equipment}

NMR spectra were recorded on a Bruker Avance spectrometer operating at $600 \mathrm{MHz}$. Samples were dissolved in deuterated methanol $\left(\mathrm{MetOH}-d_{4}\right)$ and analyzed; J values are given in Hertz. Thin-layer chromatography (TLC) was performed on silica gel 60 F254 plates (Sigma-Aldrich, Milano, Italy) and developed using a mixture of ethyl acetate/methanol 98/2 as a mobile phase. The spots were visualized under UV light at $254 \mathrm{~nm}$.

HPLC analysis were performed with a liquid Chromatograph Dynamax SD200 (VARIAN ${ }^{\circledR}$, Woburn, MA, USA), equipped with a binary pump with Rheodyne injector and a UV-VIS detector managed by the Galaxy chemstation (VARIAN, Woburn, MA, USA). A reversed phase column C18 ODS Hypersil (250 mm length, 4.6 mm ID, $5 \mu$, Phenomenex ${ }^{\circledR}$, Castel Maggiore, Italy) was used. The samples were dissolved in methanol and filtered with $0.45 \mu \mathrm{m}$ nylon filters. The conditions used are the following: flow $1 \mathrm{~mL} / \mathrm{min}, \lambda 254 \mathrm{~nm}$; solution A: trifluoroacetic acid $0.1 \%$; solution B: acetonitrile; gradient elution from B 20\% to B 60\% in $35 \mathrm{~min}$, then B 100\% in $45 \mathrm{~min}$. In this condition moringin 2 has a retention time of 18.35 min. FTIR spectra was registered on ATR 4600 Jasco instrument (Jasco Europe, Cremella, Italy). ESI-MS mass determination was performed at the COSPECT centre of the University of Milan, with a mass spectrometer ESI-Q-Tof: SYNAPT G2-Si HDMS 8k, Waters SpA, working with Masslynx software (version 2.0) and coupled with Waters Ultra Performance LC System Acquity UPLC H-Class (Waters, Sesto San Giovanni, Italy).

\subsection{Preparation of Extracts}

An aliquot of $5.03 \mathrm{~g}$ of dried powder of moringa leaves was extracted at room temperature, in sequence, with magnetic stirring with four solvents with increasing polarity: hexane, diethyl ether, dichloromethane and methanol. A drug/solvent ratio of 1/10 was used and each extraction was done twice for each solvent and each step was proceeded for 2 and a half hours. At the end of each session, the extract was filtered and collected in a volumetric flask and the solvents evaporated in vacuo. Four crude extract were obtained respectively from hexane (E1: $79.6 \mathrm{mg}, 1.59 \%)$, diethylether (E2: 15.3 $\mathrm{mg}, 0.30 \%$ ), dichloromethane (E3: $62.4 \mathrm{mg}, 1.24 \%$ ) and methanol (E4: $180.2 \mathrm{mg}, 3.58 \%$ ).

For extracts E5 and E6, the extraction of moringa leaves was performed to optimize in situ biotrasformation of glucosinolates into the corresponding isothiocyanates by myrosinase. The extracts were prepared from frozen leaves $(10 \mathrm{~g})$ in water and methanol respectively.

Frozen leaves $(10 \mathrm{~g})$ were finely crushed and resuspended in $50 \mathrm{~mL}$ of Millipore water for 30 min at room temperature. After filtration the solvent was lyophilized to obtain extract E5 (0.6994 g, $6.99 \%$ ). Frozen leaves (10 g) were finely crushed and resuspended in $20 \mathrm{~mL}$ of methanol for $4 \mathrm{~h}$ at room temperature. After filtration the solvent was evaporated to obtain extract E6 (0.126 g, 1.26\%).

The extractions were conducted according to Waterman [47].

\subsection{Isolation and Purification of Moringin}

Moringin was extracted from ground frozen leaves $(10 \mathrm{~g})$ in $\mathrm{MeOH}(20 \mathrm{~mL})$ at room temperature for $4 \mathrm{~h}$. The methanolic extract was evaporated in vacuo and partitioned in water: hexane 1:1 three times with $20 \mathrm{~mL}$ of each solvent. Finally, water phase was partitioned with ethyl acetate. Organic phase was dried and the solvent evaporated in vacuo to obtain a crude extract (0.0735 g). Purification was carried out by flash chromatography (ethyl acetate/methanol 98:2). Pure moringin was obtained as a colorless gummy powder (15 $\mathrm{mg}, 0.15 \%)$.

TLC Rf 0.25 (silica gel, ethyl acetate/methanol 98/2 v/v)

${ }^{1} \mathrm{H}$ NMR $\left(\mathrm{MeOH}-d_{4}\right) \delta: 1.22\left(3 \mathrm{H}, \mathrm{d}, J=6.1 \mathrm{~Hz}, \mathrm{CH}_{3}\right), 3.46\left(1 \mathrm{H}, \mathrm{t}, J=9.5, \mathrm{H}-4^{\prime}\right), 3.63\left(1 \mathrm{H}, \mathrm{m}, \mathrm{H}-5^{\prime}\right)$, $3.84\left(1 \mathrm{H}, \mathrm{dd}, J=3.5\right.$ and $\left.9.5 \mathrm{~Hz}, \mathrm{H}-3^{\prime}\right), 4.00\left(1 \mathrm{H}, \mathrm{bs}, \mathrm{H}-2^{\prime}\right), 4.69\left(2 \mathrm{H}, \mathrm{s}, \mathrm{CH}_{2}\right), 5.44\left(1 \mathrm{H}, \mathrm{bs}, \mathrm{H}-1^{\prime}\right), 7.09$ and 7.29 (4H, 2d, J = 8.4 Hz, arom.). ${ }^{13} \mathrm{C} \mathrm{NMR}(\mathrm{MeOH}-\mathrm{d} 4)$ ): 13.1, 46.7, 68.9, 70.2, 70.5, 72.0, 98.1, 116.1, $127.8,128.2,127.9,155.9$.

FTIR $v_{\max } 3381,\left(\right.$ br. OH), 2920, 2172, 2086, 1609, 1609, 1508, 1236, 1119, 1123, 1058, $983 \mathrm{~cm}^{-1}$. 
ESI-MS 334.0723 [M + Na ${ }^{+}, 100 \%$, (theoretical $\left.\mathrm{C}_{14} \mathrm{H}_{17} \mathrm{NO}_{5} \mathrm{SNa} 334.0720\right) ; 335.0750[\mathrm{M}+1+\mathrm{Na}]^{+}$, $20 \% ; 336.0710[\mathrm{M}+2+\mathrm{Na}]^{+}, 4 \%$. Analytical data of moringin are shown in Supplementary material.

\subsection{In Vitro Assays with rTRP Ion Channels}

Compound and extracts' effects on intracellular $\mathrm{Ca}^{2+}$ concentration $\left(\left[\mathrm{Ca}^{2+}\right]_{\mathrm{i}}\right)$ were determined using the selective intracellular fluorescent probe for $\mathrm{Ca}^{2+}$ Fluo-4. Assay of rat TRPA1, TRPV2, TRPV3, TRPV4, TRPM8 or human TRPV1 mediated elevation of intracellular $\mathrm{Ca}^{2+}$ in transfected HEK-293 cells are been performed as described [56]. Briefly, human embryonic kidney (HEK-293) cells, stably transfected with rat TRPA1, TRPV2, TRPV3, TRPV4, TRPM8 or human TRPV1 (selected by Geneticin $600 \mu \mathrm{g} \mathrm{mL} \mathrm{mL}^{-1}$ ) or not transfected, were cultured in EMEM $+2 \mathrm{mM}$ Glutamine $+1 \%$ Non-Essential Amino Acids (NEAA) + 10\% FBS and maintained at $37{ }^{\circ} \mathrm{C}$ with $5 \% \mathrm{CO}_{2}$. Stable transfections were checked by quantitative real-time polymerase chain reaction (PCR), quantitative real-time PCR was performed by an iCycler-iQ (Bio-Rad, Hercules, CA, USA) in a $20 \mu \mathrm{L}$ reaction mixture containing the following: $10 \mu \mathrm{L}$ iQ SYBR Green Supermix 2X (Bio-Rad), 20 ng of cDNA (calculated on the basis of the retro-transcribed RNA), and $330 \mathrm{nM}$ for each primer. Optimized primers for SYBR Green analysis (and relative TaOpt) and optimum annealing temperatures were designed by Allele-Id software version 7.0 (Biosoft International, Palo Alto, CA, USA) and were synthesized (HPLC-purification grade) by MWG-Biotech AG (Ebersberg, Germany). Assays were performed in quadruplicate (maximal $\Delta \mathrm{Ct}$ of replicate samples, $<0.5$ ). Relative expression analysis, correct for PCR efficiency and normalized with respect to reference genes $\beta$-actin and glyceraldehyde 3 -phosphate dehydrogenase, was performed by GENEX software (Bio-Rad). TRP-HEK-293 cells express high levels of TRP transcripts, while these transcripts were virtually absent in wild type HEK-293 cells. The day of the experiment the cells were loaded with Fluo-4 AM ( $4 \mu \mathrm{M}$ in DMSO containing $0.02 \%$ Pluronic F-127) for $1 \mathrm{~h}$ in the dark at room temperature, rinsed and resuspended in Tyrode's solution (145 mM NaCl, $2.5 \mathrm{mM} \mathrm{KCl}, 1.5 \mathrm{mM} \mathrm{CaCl}_{2}, 1.2 \mathrm{mM} \mathrm{MgCl} 2,10 \mathrm{mM}$-glucose, and $10 \mathrm{mM}$ HEPES, $\mathrm{pH}$ 7.4), finally transferred to a quartz cuvette of a spectrofluorimeter (Perkin-Elmer LS50B; $\lambda \mathrm{EX}=$ $488 \mathrm{~nm}, \lambda \mathrm{EM}=516 \mathrm{~nm}$ ) equipped with PTP-1 Fluorescence Peltier System (PerkinElmer Life and Analytical Sciences, Waltham, MA, USA) under continuous stirring. Cell fluorescence before and after the addition of various concentrations of test compounds and extracts were measured normalizing the effects against the response to ionomycin $(4 \mu \mathrm{M})$. The values of the effect on $\left[\mathrm{Ca}^{2+}\right]_{\mathrm{i}}$ in $\mathrm{HEK}-293$ cells not transfected are used as baseline and subtracted from the values obtained from transfected cells. For TRPA1 agonist efficacy was expressed as a percentage of the effect on $\left[\mathrm{Ca}^{2+}\right]_{\mathrm{i}}$ observed with $100 \mu \mathrm{M}$ allylisothiocyanate (AITC). In our experiment on rTRPA1 HEK-293 cells $100 \mu \mathrm{M}$ allyl isothiocyanate (AITC) exerts an efficacy of $52.4 \pm 4.4 \%$ of the response to ionomycin $4 \mu \mathrm{M}$, while it shows only a negligible effect on not transfected HEK-293 cells (about 1\%). The potency of the compounds ( $\mathrm{EC}_{50}$ values) are determined as the concentration required to produce half-maximal increases in $\left[\mathrm{Ca}^{2+}\right]_{i}$. In TRPV3 assay TRPV3-expressing HEK293 cells were first sensitized with the structurally unrelated agonist 2-aminoethoxydiphenyl borate (100 $\mu \mathrm{M})$. Antagonist/desensitizing behaviour is evaluated against the agonist of the TRP analyzed by adding the compounds directly in the quartz cuvette 5 min before stimulation of cells with the agonist. In particular, we used AITC $100 \mu \mathrm{M}$ for TRPA1, capsaicin $0.1 \mu \mathrm{M}$ for TRPV1, lysophosphatidylcholine (LPC) $3 \mu \mathrm{M}$ for TRPV2, thymol 100 $\mu \mathrm{M}$ for TRPV3, GSK1016790A 10nM for TRPV4 and icilin $0.25 \mu \mathrm{M}$ for TRPM8. In order to assess functional antagonism of TRPA1 channels, AP18, 4-(4-chlorophenyl)-3-methyl-3-buten-2-one oxime [57] $50 \mu \mathrm{M}$ was pre-incubated with the cells, for $5 \mathrm{~min}$ before the addition of AITC (100 $\mu \mathrm{M})$ and moringin $(10 \mu \mathrm{M}) . \mathrm{IC}_{50}$ is expressed as the concentration exerting a half-maximal inhibition of agonist effect, taking as $100 \%$ the effect on $\left[\mathrm{Ca}^{2+}\right]_{i}$ exerted by the agonist alone. Dose-response curve fitting (sigmoidal dose-response variable slope) and parameter estimation were performed with Graph-Pad Prism8 ${ }^{\circledR}$ (GraphPad Software Inc., San Diego, CA, USA). All determinations were performed at least in triplicate. Time-course of calcium bound Fluo- 4 fluorescence intensity in rTRPA1 experiments are shown in Supplementary material. 
Supplementary Materials: The following are available online at, S1: Analytical data of moringin; S2: Time-course of calcium bound Fluo-4 fluorescence intensity in rTRPA1 experiments.

Author Contributions: Conceptualization, Angela Bassoli, G.B, and L.D.P; methodology, G.B. and L.D.P; formal analysis, G.B., P.D.N, A.S.M., A.L., Alberto Battezzati, and S.M.; resources: S.B. and Alberto Battezzati, A.L.; writing-original draft preparation, Angela Bassoli, G.B, and L.D.P.; writing-review and editing, Angela Bassoli, G.B, L.D.P., A.S.M., and S.B. All authors have read and agreed to the published version of the manuscript.

Funding: This research received no external funding.

Acknowledgments: We are deeply grateful to Dr. Babahmed Mohamed-Iahdih and Centro Experimental de Formación Agrícola (CEFA), Ministerio de Desarrollo Económico, República Árabe Saharaui Democrática, for providing us Moringa oleifera leaf samples.

Conflicts of Interest: The authors declare no conflict of interest.

\section{References}

1. Rani, N.Z.A.; Husain, K.; Kumolosasi, E. Moringa Genus: A Review of Phytochemistry and Pharmacology. Front. Pharmacol. 2018, 9, 108. [CrossRef]

2. Leone, A.; Spada, A.; Battezzati, A.; Schiraldi, A.; Aristil, J.; Bertoli, S. Cultivation, Genetic, Ethnopharmacology, Phytochemistry and Pharmacology of Moringa oleifera Leaves: An Overview. Int. J. Mol. Sci. 2015, 16, 12791-12835. [CrossRef]

3. Leone, A.; Bertoli, S.; Di Lello, S.; Bassoli, A.; Ravasenghi, S.; Borgonovo, G.; Forlani, F.; Battezzati, A. Effect of Moringa oleifera leaf powder on postprandial blood glucose response: In vivo study on Saharawi people living in refugee camps. Nutrients 2018, 10, 1494. [CrossRef]

4. Rodríguez-Pérez, C.; Quirantes-Pinéb, R. Optimization of extraction method to obtain a phenolic compounds-rich extract from Moringa oleifera Lam. Leaves. Ind. Crops Prod. 2015, 66, 246-254. [CrossRef]

5. Dinkova-Kostova, A.T.; Kostov, R.V. Glucosinolates and isothiocyanates in health and disease. Trends Mol. Med. 2012, 18, 337-347. [CrossRef]

6. Galuppo, M.; De Nicola, G.R.; Iori, R.; Dell'Utri, P.; Bramanti, P.; Mazzon, E. Antibacterial activity of glucomoringin bioactivated with myrosinase against two important pathogens affecting the health of long-term patients in hospitals. Molecules 2013, 18, 14340-14348. [CrossRef]

7. Guimaraes, M.Z.P.; Jordt, S. TRPA1: A sensory channel of many talents. In TRP Ion Channel Function in Sensory Transduction and Cellular Signaling Cascades; Liedtke, W.B., Ed.; CRC press/Taylor\&Francis: Boca raton, FL, USA, 2007; pp. 151-161.

8. Jaafaru, M.S.; Nordin, N.; Shaari, K.; Rosli, R.; Abdull Razis, A.F. Isothiocyanate from Moringa oleifera seeds mitigates hydrogen peroxide-induced cytotoxicity and preserved morphological features of human neuronal cells. PLoS ONE 2018, 13, e0196403. [CrossRef]

9. Haristoy, X.; Fahey, J.W.; Scholtus, I.; Lozniewski, A. Evaluation of the antimicrobial effects of several isothiocyanates on Helicobacter pylori. Planta Med. 2005, 71, 326-330. [CrossRef]

10. Padla, E.P.; Solis, L.T.; Levida, R.M.; Shen, C.C.; Ragasa, C.Y. Antimicrobial Isothiocyanates from the Seeds of Moringa oleifera Lam. Z. Naturforsch. C. 2012, 67, 557-564. [CrossRef]

11. Dzotam, J.K.; Touani, F.K.; Kuete, V. Antibacterial and antibiotic-modifying activities of three food plants. (Xanthosoma mafaffa Lam., Moringa oleifera (L.) Schott and Passiflora edulis Sims) against multidrug-resistant (MDR) Gram-negative bacteria. BMC Complement. Altern. Med. 2016, 16, 9. [CrossRef]

12. Anwar, F.; Latif, S.; Ashraf, M.; Gilani, A.H. Moringa oleifera: A food plant with multiple medicinal uses. Phytother. Res. 2007, 21, 17-25. [CrossRef] [PubMed]

13. Müller, C.; van Loon, J.; Ruschioni, S.; De Nicola, G.R.; Iori, R.; Agerbirk, N.; Olsen, C.E. Taste detection of the non-volatile isothiocyanate moringin results in deterrence to glucosinolate-adapted insect larvae. Phytochemistry 2015, 118, 139-148.

14. Jaja-Chimedza, A.; Graf, B.L.; Simmler, C.; Kim, Y.; Kuhn, P.; Pauli, G.F.; Raskin, I. Biochemical characterization and anti-inflammatory properties of an isothiocyanate-enriched moringa (Moringa oleifera) seed extract. PLoS ONE 2017, 12, e0182658. [CrossRef] [PubMed]

15. Rajan, T.S.; De Nicola, G.R.; Iori, R.; Rollin, P.; Bramanti, P.; Mazzon, E. Anticancer activity of glucomoringin isothiocyanate in human malignant astrocytoma cells. Fitoterapia 2016, 110, 1-7. [CrossRef] 
16. Solomon, H. Methodology for rapid isolation of moringin: Potential anticancer compound from the seeds of Moringa stenopetala. Pharmaceutica Analytica Acta 2017, 8, 558/1-558/7.

17. Chiricosta, L.; Gugliandolo, A.; Diomede, F.; Pizzicannella, J.; Trubiani, O.; Iori, R.; Tardiolo, G.; Guarnieri, S.; Bramanti, P.; Mazzon, E. Moringin Pretreatment Inhibits the Expression of Genes Involved in Mitophagy in the Stem Cell of the Human Periodontal Ligament. Molecules 2019, 24, 3217. [CrossRef]

18. Sani, J.M.; Karim, A.; Ashikin, N.; Eliaser, E.M.; Patrick, R.; Mazzon, E.; Razis, A.; Faizal, A. Protective effect of glucosinolates hydrolytic products in neurodegenerative diseases (NDDs). Nutrients 2018, 10, 580. [CrossRef]

19. Chiricosta, L.; Silvestro, S.; Pizzicannella, J.; Diomede, F.; Bramanti, P.; Trubiani, O.; Mazzon, E. Transcriptomic Analysis of Stem Cells Treated with Moringin or Cannabidiol: Analogies and Differences in Inflammation Pathways. Int. J. Mol. Sci. 2019, 20, 6039. [CrossRef]

20. Galuppo, M.; Giacoppo, S.; Iori, R.; De Nicola, G.; Milardi, D.; Bramanti, P.; Mazzon, E. 4( $\alpha-\mathrm{L}$ Rhamnosyloxy)benzyl isothiocyanate, a bioactive phytochemical that defends cerebral tissue and prevents severe damage induced by focal ischemia/reperfusion. J. Biol. Regul. Homeost. Agents 2015, 29, 343-356.

21. Galuppo, M.; Giacoppo, S.; Iori, R.; De Nicola, G.R.; Bramanti, P.; Mazzon, E. Administration of 4- $(\alpha-\mathrm{L}$ rhamnosyloxy)-benzyl isothiocyanate delays disease phenotype in SOD1G93A rats: A transgenic model of amyotrophic lateral sclerosis. Biomed. Res. Int. 2015, 5, 259417. [CrossRef]

22. Wang, X.; Liu, Y.; Liu, X.; Lin, Y.; Zheng, X.; Lu, Y. Hydrogen Sulfide $\left(\mathrm{H}_{2} \mathrm{~S}\right)$ Releasing Capacity of Isothiocyanates from Moringa oleifera Lam. Molecules 2018, 23, 2809. [CrossRef] [PubMed]

23. Mannelli, C.; Lucarini, E.; Micheli, L.; Mosca, I.; Ambrosino, P.; Soldovieri, M.V.; Martelli, A.; Testai, L.; Taglialatela, M.; Calderone, V.; et al. Effects of natural and synthetic isothiocyanate-based $\mathrm{H}_{2} \mathrm{~S}$-releasers against chemotherapy-induced neuropathic pain: Role of Kv7 potassium channels. Neuropharmacology 2017, 121, 49-59. [CrossRef] [PubMed]

24. Martinez-Gonzalez, C.L.; Martinez-Ortiz, E.J.; Martinez, L.; Gonzalez-Trujano, M.E.; Deciga-Campos, M.; Ventura-Martinez, R.; Diaz-Reval, I. Moringa oleifera, a species with potential analgesic and anti-inflammatory activities. Biomed. Pharmacother. 2017, 87, 482-488. [CrossRef] [PubMed]

25. Mahdi, H.J.; Khan, N.A.K.; Asmawi, M.Z.B.; Mahmud, R.; Murugaiyah, V. In vivo anti-arthritic and anti-nociceptive effects of ethanol extract of Moringa oleifera leaves on complete Freund's adjuvant (CFA)-induced arthritis in rats. Int. Med. Res. 2018, 7, 85-94. [CrossRef] [PubMed]

26. Giacoppo, S.; Iori, R.; Bramanti, P.; Mazzon, E. Topical moringin cream relieves neuropathic pain by suppression of inflammatory pathway and voltage-gated ion channels in murine model of multiple sclerosis. Mol. Pain 2017, 13, 1-17. [CrossRef] [PubMed]

27. Mathiron, D.; Iori, R.; Pilard, S.; Rajan, T.S.; Landy, D.; Mazzon, E.; Rollin, P.; Djedaïni-Pilard, F.A. Combined Approach of NMR and Mass Spectrometry Techniques Applied to the $\alpha$-Cyclodextrin/Moringin Complex for a Novel Bioactive Formulation. Molecules 2018, 23, 1714. [CrossRef]

28. Venkatachalam, K.; Montell, C. TRP channels. Ann. Rev. Biochem. 2007, 76, 387-417. [CrossRef]

29. Nilius, B.; Owsianik, G. The transient receptor potential family of ion channels. Genome Biol. 2011, 12, 218-229. [CrossRef]

30. Nilius, B.; Appendino, G. Spices: The savory and beneficial science of pungency. Rev. Physiol. Biochem. Pharmacol. 2013, 164, 1-76.

31. Nilius, B.; Appendino, G.; Owsianik, G. The Transient Receptor Potential Channel TRPA1: From gene to pathophysiology. Pflugers Arch. 2012, 464, 425-458. [CrossRef]

32. Anand, U.; Otto, W.R.; Facer, P.; Zebda, N.; Selmer, I.; Gunthorpe, M.J.; Chessell, I.P.; Sinisi, M.; Birch, R.; Anand, P. TRPA1 receptor localisation in the human peripheral nervous system and functional studies in cultured human and rat sensory neurons. Neurosci. Lett. 2008, 438, 221-227. [CrossRef] [PubMed]

33. Atoyan, R.; Shander, D.; Botchkareva, N.V. Non-neuronal expression of transient receptor potential type A1 (TRPA1) in human skin. J. Invest. Dermatol. 2009, 129, 2312-2315. [CrossRef] [PubMed]

34. Nassini, R.; Pedretti, P.; Moretto, N.; Fusi, C.; Carnini, C.; Facchinetti, F.; Viscomi, A.R.; Pisano, A.R.; Stokesberry, S.; Brunmark, C.; et al. Transient receptor potential ankyrin 1 channel localized to non-neuronal airway cells promotes non-neurogenic inflammation. PLoS ONE 2012, 7, e42454. [CrossRef] [PubMed]

35. Nassini, R.; Materazzi, S.; Vriens, J.; Prenen, J.; Benemei, S.; De Siena, G.; la Marca, G.; Andrè, E.; Preti, D.; Avonto, C.; et al. The 'headache tree' via umbellulone and TRPA1 activates the trigeminovascular system. Brain 2012, 135, 376-390. [CrossRef] [PubMed] 
36. Bandell, M.; Story, G.M.; Hwang, S.W.; Viswanath, V.; Eid, S.R.; Petrus, M.J.; Earley, T.J.; Patapoutian, A. Noxious cold ion channel TRPA1 is activated by pungent compounds and bradykinin. Neuron 2004, 41, 849-857. [CrossRef]

37. Bautista, D.M.; Movahed, P.; Hinman, A.; Axelsson, H.E.; Sterner, O.; Högestätt, E.D.; Julius, D.; Jordt, S.V.; Zygmunt, P.M. Pungent products from garlic activate the sensory ion channel TRPA1. Proc. Nat.Acad. Sci. USA 2005, 102, 12248-12252. [CrossRef]

38. Macpherson, L.J.; Geierstanger, B.H.; Viswanath, V.; Bandell, M.; Eid, S.R.; Hwang, S.; Patapoutian, A. The pungency of garlic: Activation of TRPA1 and TRPV1 in response to allicin. Curr Biol. 2005, 15, 929-934. [CrossRef]

39. Jordt, S.E.; Bautista, D.M.; Chuang, H.H.; McKemy, D.D.; Zygmunt, P.M.; Högestätt, E.D.; Meng, I.D.; Julius, D. Mustard oils and cannabinoids excite sensory nerve fibres through the TRP channel ANKTM1. Nature 2004, 427, 260-265. [CrossRef]

40. Hinman, A.; Chuang, H.H.; Bautista, D.M.; Julius, D. TRP channel activation by reversible covalent modification. PNAS 2006, 103, 19564-19568. [CrossRef]

41. Paulsen, C.; Armache, J.; Gao, Y.; Cheng, Y.; Julius, D. Structure of the TRPA1 ion channel suggests regulatory mechanisms. Nature 2015, 520,511-517. [CrossRef]

42. Cavanaugh, E.J.; Simkin, D.; Kim, D. Activation of transient receptor potential A1 channels by mustard oil, tetrahydrocannabinol and $\mathrm{Ca}^{2+}$ reveals different functional channel states. Neurosciences 2008, 154, 1467-1476. [CrossRef] [PubMed]

43. Simon, S.A.; Gutierrez, R. TRP Channels at the Periphery of the Taste and Trigeminal Systems. In Neurobiology of TRP Channels, 2nd ed.; Emir, T.L.R., Ed.; CRC Press/Taylor\&Francis: Boca raton, FL, USA, 2017; Chapter 7. [CrossRef]

44. Borgonovo, G.; Zimbaldi, N.; Guarise, M.; De Nisi, P.; De Petrocellis, L.; Schiano Moriello, A.; Bassoli, A. Isothiocyanates and Glucosinolates from Sisymbrium officinale (L.) Scop. ("the Singers' Plant"): Isolation and in Vitro Assays on the Somatosensory and Pain Receptor TRPA1 Channel. Molecules 2019, 24, 949. [CrossRef] [PubMed]

45. González-Ramírez, R.; Chen, Y.; Liedtke, W.B.; Morales-Lázaro, S.L. TRP Channels and Pain. In Neurobiology of TRP Channels, 2nd ed.; Emir, T.L.R., Ed.; CRC Press/Taylor\&Francis: Boca raton, FL, USA, 2017; chapter 8. [CrossRef]

46. Mickle, A.D.; Shepherd, A.J.; Mohapatra, D.P. Nociceptive TRP Channels: Sensory Detectors and Transducers in Multiple Pain Pathologies. Pharmaceuticals 2016, 9, 72. [CrossRef] [PubMed]

47. Waterman, C.; Cheng, D.M.; Rojas-Silva, P.; Poulev, A.; Dreifus, J.; Lila, M.A.; Raskin, I. Stable, water extractable isothiocyanates from Moringa oleifera leaves attenuate inflammation in vitro. Phytochemistry 2014, 103, 114-122. [CrossRef] [PubMed]

48. De Graaf, R.M.; Krosse, S.; Swolfs, A.M.; te Brinke, E.; Prill, N.; Leimu, R.; van Galen, P.M.; Wang, Y.; Aarts, M.G.M.; van Dam, N.M. Isolation ad identification of 4- $\alpha$-rhamnosyloxy benzyl glucosinolate in Noccaea caerulescens showung intraspecific variation. Phytochemistry 2015, 110, 166-171. [CrossRef] [PubMed]

49. Del Prete, D.; Caprioglio, D.; Appendino, G.; Minassi, A.; Schiano-Moriello, A.; Di Marzo, V.; De Petrocellis, L. Discovery of non-electrophilic capsaicinoid-type TRPA1 ligands. Bioorg. Med. Chem. Lett. 2015, 25, 1009-1011. [CrossRef]

50. Nalli, M.; Ortar, G.; Schiano Moriello, A.; Di Marzo, V.; De Petrocellis, L. Effects of curcumin and curcumin analogues on TRP channels. Fitoterapia 2017, 122, 126-131. [CrossRef]

51. Akopian, A.N.; Ruparel, N.B.; Jeske, N.A.; Hargreaves, K.M. Transient receptor potential TRPA1 channel desensitization in sensory neurons is agonist dependent and regulated by TRPV1-directed internalization. J. Physiol. 2007, 583, 175-193. [CrossRef]

52. Ruparel, N.B.; Patwardhan, A.M.; Akopian, A.N.; Hargreaves, K.M. Homologous and heterologous desensitization of capsaicin and mustard oil responses utilize different cellular pathways in nociceptors. Pain 2008, 135, 271-279. [CrossRef]

53. Sulaiman, M.R.; Zakaria, Z.A.; Bujarimin, A.S.; Somchit, M.N.; Israf, D.A.; Moin, S. Evaluation of Moringa oleifera Aqueous Extract for Antinociceptive and Anti-Inflammatory Activities in Animal Models. Pharm. Biol. 2008, 46, 838-845. [CrossRef] 
54. Manguro, L.O.; Lemmen, P. Phenolics of Moringa oleifera leaves. Nat. Prod Res. 2007, 21, 56-68. [CrossRef] [PubMed]

55. Nakamura, T.; Miyoshi, N.; Ishii, T.; Nishikawa, M.; Ikushiro, S. Activation of transient receptor potential ankyrin 1 by quercetin and its analogs. Biosci. Biotechnol. Biochem. 2016, 80, 949-954. [CrossRef] [PubMed]

56. Schiano-Moriello, A.; De Petrocellis, L. Assay of TRPV1 Receptor Signaling. Methods Mol. Biol. 2016, 1412, 65-76.

57. Defalco, J.; Steiger, D.; Gustafson, A.; Emerling, D.E.; Kelly, M.G.; Duncton, M.A. Oxime derivatives related to AP18: Agonists and antagonists of the TRPA1 receptor. Bioorg. Med. Chem. Lett. 2010, 20, 276-279. [CrossRef]

Sample Availability: Samples of the compounds 1 and 2 are not available from the authors.

(C) 2020 by the authors. Licensee MDPI, Basel, Switzerland. This article is an open access article distributed under the terms and conditions of the Creative Commons Attribution (CC BY) license (http://creativecommons.org/licenses/by/4.0/). 